\title{
Conjugation of small molecules to RNA using a reducible disulfide linker attached at 2'-OH position via a carbamate function
}

\author{
Florian Gauthier, ${ }^{[a]}$ Astrid Malher, ${ }^{[a]}$ Jean-Jacques Vasseur, ${ }^{[a]}$ Christelle Dupouy, ${ }^{[a]}$ and Françoise \\ Debart *[a]
}

\begin{abstract}
A post-synthesis conjugation method was developed to functionalize oligoribonucleotides with various small molecules of biological interest using a reduction-sensitive disulfide linker connected to $2^{\prime} \mathrm{OH}$ via a carbamate function. For this, first we prepared a 2'-O-[( $N$-(acetylthio)-ethylcarbamoyl] (2'-O-AcSEC) uridine phosphoramidite as the key precursor of the disulfide linker, that was incorporated into 21-mer RNAs. Next the 2'-O-AcSEC group was converted on solid support to the activated 2'-O-[N-(2pyridyldisulfanyl)-ethylcarbamoyl] (2'-O-PySSEC) group. Finally, the coupling between 2'-O-PySSEC-modified RNA and diverse small molecules bearing a thiol function was based on a thiol-disulfide exchange reaction in solution. Several RNA-small molecule conjugates were obtained with satisfactory conjugation yields. An RNA was successfully double-conjugated with an anticancer drug (doxorubicin) attesting the efficiency and the robustness of the conjugation method. We have shown that the disulfide-linked RNAsmall molecule conjugates were cleaved upon $5.6 \mathrm{mM}$ glutathione treatment, featuring the release of the small molecules in cells.
\end{abstract}

\section{Introduction}

Conjugation of oligonucleotides (ON) with small molecules is challenging and arouses researcher's interest for diverse applications such as therapeutics or diagnosis. Covalent association to small molecules such as peptides, carbohydrates or lipids could improve ON properties such as cell-specific delivery, cellular uptake efficiency or half-lives in fluids. ${ }^{[1]}$ Carbohydrates are recognized by protein receptors named lectins expressed on cell surfaces. As glycoproteins containing sugar moieties are internalized into cells, ON-carbohydrate conjugates can therefore be used to improve poor cell or tissue-specific uptake of $\mathrm{ON}^{[2]}$ In particular, $\mathrm{N}$-acetylgalactosamine (GalNAc) siRNA conjugates should be mentioned as one significant and relevant example of the successful use of sugar-oligonucleotide

[a] IBMM, University of Montpellier, CNRS, ENSCM, Montpellier, France

E-mail: christelle.dupouy@umontpellier.fr francoise.debart@umontpellier.fr

Supporting information for this article is given via a link at the end of the document conjugates for delivery to liver hepatocytes. ${ }^{[3]}$ Conjugation of small molecules to ON could also be used for detection. Recently, coumarin derivative attached to $\mathrm{ON}$ was used as a fluorescent probe to specifically detect glutathione, the most abundant biothiol over cysteine and homocysteine. ${ }^{[4]}$ Moreover, vitamins receptors, such as biotin receptors, are overexpressed in many cancers and consequently were used as biomarkers for the imaging and the detection of tumors cells or the targeting of drug delivery. ${ }^{[5]}$

Attachment of small molecules to ON using various chemical strategies with amide ${ }^{[6]}$ or oxime ${ }^{[7]}$ linkers or via click chemistry ${ }^{[8]}$ has been reported. Due to its high compatibility with many functional groups and the ease of formation, the disulfide bond is also very attractive for conjugation. Indeed, this linkage is stable under physiological conditions and is cleaved in the intracellular reducing environment. ${ }^{[9]}$ The conjugation reactions using a disulfide linkage were mostly achieved at the 5'- and 3'-end positions of $\mathrm{ON}$ due to their great accessibility. ${ }^{[10]}$ Likewise, the nucleobases ${ }^{[11]}$ and the phosphodiester bonds ${ }^{[12]}$ were selected as other conjugation sites. However, these positions suffer from different various limitations: only one molecule can be conjugated to $\mathrm{ON}$ at 5'- or 3'-end, the base-pairing can be disturbed by conjugation on the nucleobases and RNA structure can be altered by modifications of the phosphates. In contrast, the 2'-position is more versatile and allows multi-conjugation sites within one sequence. To our knowledge, only a few examples of conjugation to 2'-position of ribonucleosides via a disulfide linkage have been reported. Winkler and coll. developed a solid-phase coupling of peptides and polyethylene glycols ligands to ON via a 2'-Othioethyl nucleoside attached to the solid support through the thiol function. ${ }^{[13]}$

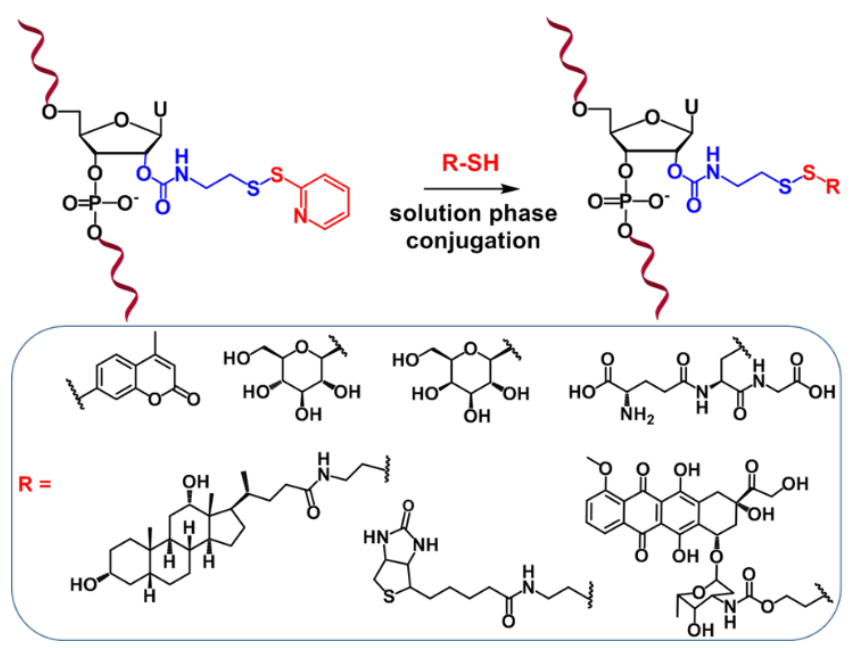


Scheme. 1 Synthesis of 2'-O-[N-(2-ethyldisulfanyl) carbamoyl] RNA-smallmolecule conjugates.

This method is efficient yet only the 3'-extremity of ON can be conjugated. Another example of conjugation reaction at the 2'position with a disulfide linker has been reported for the specific cross-linking of proteins via cysteine to ON. In this case, a 2'amino-2'-deoxyuridine was introduced as a precursor unit within the ON sequence then the amino group was converted to 2'pyridyldithiopropionamide derivative to perform the thiol-disulfide exchange reaction with cysteine yielding the disulfide linker. ${ }^{[14]}$ Moreover, in a previous work we developed a post-synthesis strategy based on the thiol-disulfide exchange reaction for the preparation of SiRNA prodrugs 2'-O-modified by disulfidecontaining groups. ${ }^{[15]}$ We also used this reaction to introduce a disulfide-bridge between 2'-O-positions of two adjacent nucleotides in the loop of RNA hairpins. ${ }^{[16]}$ In both cases, the disulfide bond was anchored to the nucleoside via a thioacetal function. Reduction of the disulfide bond resulted in an unstable hemithioacetal giving rise to free 2'-OH RNA.

In this paper, we present a post-synthesis conjugation method of a 21-mer RNA to various small molecules of interest such as carbohydrates, lipids, vitamins, fluorescent probes and anticancer drugs using a disulfide linker attached at 2'-position via a carbamate function (Scheme 1). It is well known that carbamate function plays an important role in medicinal chemistry due to its high stability in physiological conditions. ${ }^{[17]}$ Moreover, several functional groups (dansyl, amino aliphatic chains) were previously introduced into the $2{ }^{\prime} \mathrm{OH}$ position of $\mathrm{ON}$ via a carbamate function. ${ }^{[18]} 2$ '-carbamate modification is stable to conditions of standard oligonucleotide synthesis using phosphoramidite chemistry. The 2'-carbamate functionalization of RNA with various biomolecules for many applications, via a reductionresponsive disulfide linker remained quite unexplored. The global strategy for the synthesis of these RNA-small molecule conjugates is based on a thiol-disulfide exchange reaction between a small molecule containing a thiol or a thiolate function and an RNA bearing a pyridyldisulfanyl group (Scheme 1). The driving force of this reaction is the formation and elimination of the pyridine-2-thione, which allows a rapid and irreversible reaction.

\section{Results and Discussion}

Synthesis of 2'-O-AcSEC uridine phosphoramidite 7. To anchor the linker at 2'-position of RNA, we first prepared 2'-O-[( $N$ (acetylthio)-ethylcarbamoyl] (2'-O-AcSEC) uridine 3'phosphoramidite 7 which represents the precursor unit for 2'functionalization within RNA sequence (Scheme 2). The 2'carbamate modification was achieved via a 2'-O-carbonate intermediate 2 obtained with 81\% yield by treating 3',5'-O(1,1,3,3-tetraisopropyldisiloxane-1,3-diyl) (TIPS) uridine 1 with 4nitrophenylchloroformate. ${ }^{[18 b]} \quad$ The 2'-O-[N-ethylbromide carbamoyl] uridine $\mathbf{3}$ was formed with 2-bromoethylamine hydrobromide in $98 \%$ yield. Then, a nucleophilic substitution of bromine by potassium thioacetate in the presence of 18-crown- 6 gave 2'-O-AcSEC uridine 4 in $80 \%$ yield. A treatment with $\mathrm{Et}_{3} \mathrm{~N}$.3HF yielded the 3', 5'-OH 2'-O-AcSEC uridine 5 (92 \% yield), which was further selectively protected at 5'-O-position with a dimethoxytrityl group to give the nucleoside 6 ( $98 \%$ yield). Finally, phosphitylation of $\mathbf{6}$ with chloro-(2-cyanoethoxy)( $N, N$,diisopropylamino)phosphine afforded the 3'phosphoramidite 2'-O-AcSEC uridine 7 with high purity in $89 \%$ yield. The synthesis of 2'-O-AcSEC uridine phosphoramidite 7 was efficiently achieved in 6 steps with $51 \%$ overall yield from 5', 3'-O-TIPS-uridine 1

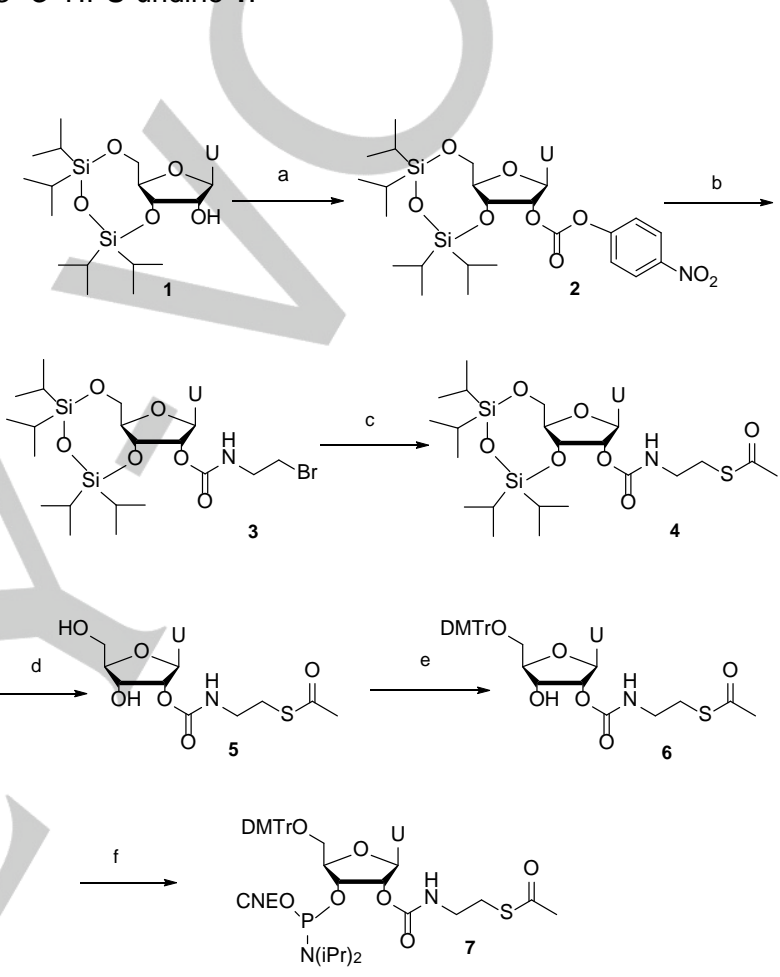

Scheme 2. Synthesis of 2'-O-AcSEC uridine phosphoramidite 7. Reagent and conditions : a) 4-nitrophenyl chloroformate, pyridine, toluene, r.t., 5 h, $81 \%$; b) 2-bromoethylamine hydrobromide, $\mathrm{Et}_{3} \mathrm{~N}$, pyridine, r.t., $4 \mathrm{~h}, 98 \%$; c) $\mathrm{CH}_{3} \mathrm{COSK}$, 18-crown-6, $\mathrm{CH}_{3} \mathrm{CN}$, r.t., overnight, $80 \%$; d) $\mathrm{Et}_{3} \mathrm{~N} .3 \mathrm{HF}$, THF, r.t., 4 h, $92 \%$; e) DMTrCl, DIEA, pyridine, $\mathrm{CH}_{2} \mathrm{Cl}_{2}$, r.t., 7 h, $98 \%$; f) $\mathrm{iPr}_{2} \mathrm{NPCl}(\mathrm{OCNE})$, DIEA, $\mathrm{CH}_{2} \mathrm{Cl}_{2}$, r.t., 3.5 h, $89 \%$

Synthesis of 21-mer RNAs with one or two 2'-O-PySSEC modifications. The 2'-O-AcSEC uridine phosphoramidite 7 was incorporated once or twice into 21-mer RNA whose sequence corresponds to the sense strand of a siRNA (siEF-4S) targeting a gene involved in Ewing's sarcoma. The 2'-O-modification was introduced either in the middle of the sequence (RNA 8) or at two sites: in the middle and close to the 3'-end (RNA 9) (Table 1). Both RNAs were synthesized using the phosphoramidite uridine 7 and commercially available 2'-O-pivaloyloxymethyl (2'-O-PivOM) ribonucleoside phosphoramidites (Chemgenes) as precursors of 2'OH ribonucleotides. ${ }^{[19]}$ From the same 2'-O-AcSEC RNA precursor, various 2'-O-functionalized RNAs with different molecules bearing a thiol function can be prepared. The syntheses were carried out on a $1 \mu \mathrm{mol}$ scale with a $180 \mathrm{~s}$ 
coupling step. After RNA assembly, an activation step of the thiol function into pyridyldisulfanyl ethylcarbamate (2'-O-PySSEC) was performed on solid support, by treating 2'-O-AcSEC RNAs with a large excess of 2,2'-dithiodipyridine (1000 equiv. per modification) in anhydrous $\mathrm{BuNH}_{2} / \mathrm{THF}(1 / 3)$ solution for $15 \mathrm{~min}$. During this reaction, cyanoethyl protecting groups were also removed from phosphates. Then 2'-O-PySSEC RNAs were released from solid support and deprotected (nucleobases and 2'-OH) with an aqueous concentrated ammonia solution for $3 \mathrm{~h}$ at $30^{\circ} \mathrm{C}$. Crude 2'-O-PySSEC RNAs 8 and $\mathbf{9}$ were purified by Ion-Exchange HPLC (IEX-HPLC), characterized by MALDI-TOF mass spectrometry and obtained with high purity (Figures S10-S11, Supplementary Information).

Table 1. Synthesis of 2'-O-PySSEC RNAs 8 and $\mathbf{9}$ 


$$
\begin{aligned}
& \text { CNEO-P=O OPivOM }
\end{aligned}
$$

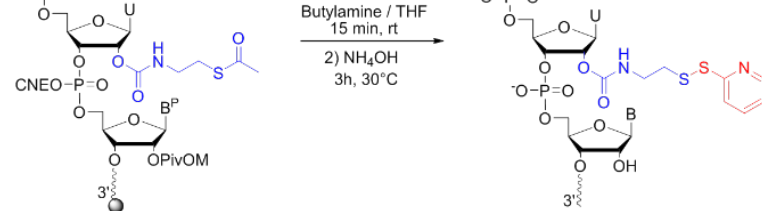

$\mathrm{B}^{\mathrm{P}}=N^{4}$-acetyl cytosine $(\mathbf{a}) ; N^{6}$-Pac adenine $(\mathbf{b}) ; N^{2}$-Pac guanine $(\mathbf{c}) ;$ uracile $(\mathbf{d})$. Pac : phenoxyacetyl group 


\begin{tabular}{|c|c|c|c|}
\hline \multirow{2}{*}{ RNA } & \multirow{2}{*}{ Sequence ${ }^{[a]}$} & \multicolumn{2}{|c|}{ MALDI-TOF MS ${ }^{[b]}$} \\
\hline & & Calcd. & Found \\
\hline SiEF-4S & ${ }^{5}$ GCAGCAGAACCCUUCUUAUGA ${ }^{3}$ & 1 & 1 \\
\hline 8 & ${ }^{5} G C A G C A G A A C C C U_{R} \cup C U U A \cup G A{ }^{3 '}$ & 6867.4 & 6867.9 \\
\hline 9 & 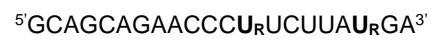 & 7079.7 & 7079.5 \\
\hline
\end{tabular}

[a] $\mathbf{U}_{\mathbf{R}}=$ 2'-O-PySSEC Uridine. [b] Negative mode

Conjugation of 2'-O-PySSEC RNA to various small molecules. A large variety of molecules such as galactose, glucose, glutathione deoxycholic acid, biotin, 4-methylcoumarin and doxorubicin (Dox) have been anchored to a 21-mer RNA (Scheme 1). Moreover, this RNA has been functionalized at one or two separate sites with Dox, an anthracycline cytotoxic chemotherapeutic drug employed for the treatment of several cancers such as breast, stomach, soft tissue sarcomas and lymphomas cancers. 2'-O-PySSEC RNA 8 was conjugated in solution to small molecules $\mathbf{1 0 - 1 6}$ bearing thiol or disulfide functions using a thiol-disulfide exchange reaction (Figure 1 , Table 2). For the coupling, two slightly different methods A and B were investigated depending on the commercial availability of the thiol derivative for each small molecule.
Method A corresponds to the direct coupling of commercially available thiol compounds such as 1-thio- $\beta$-D-glucose 10, 1-thio$\beta$-D-galactose 11, glutathione 12 and 7-mercapto-4methylcoumarin 13 to 2'-O-PySSEC RNA 8. The reactions were performed in HEPES buffer $(\mathrm{pH}=8)$ at $37^{\circ} \mathrm{C}$ for $24 \mathrm{~h}$ except for coumarin derivative 13 where DMF $(50 \%)$ was added to improve solubility (Table 2). After coupling completion, the resulting conjugates were purified by IEX-HPLC and characterized by MALDI-TOF mass spectrometry (Table 2, Figures S12-S15). For example, Figure 2a shows the HPLC chromatograms of the crude conjugates resulting from the coupling between RNA 8 with 1-thio$\beta$-D-glucose 10 (left panel) or glutathione 12 (right panel), respectively. In both cases, the major peak representing $63 \%$ and $70 \%$ was assigned to RNA conjugates 17 and 19 obtained with reasonable efficacy. RNA conjugates 18 and 20 , corresponding to the functionalization of RNA $\mathbf{8}$ with 1-thio- $\beta$-D-galactose $\mathbf{1 1}$ and 7-mercapto-4-methylcoumarin 13 respectively, were obtained with higher efficacy $(85 \%$ and $72 \%$ calculated by integration of chromatogram at $260 \mathrm{~nm}$ ) (Table 2).

However, after IEX-HPLC purification all conjugates were isolated with much lower recovery yields (from $36 \%$ for $\mathbf{1 7}$ to $46 \%$ for $\mathbf{1 8}$ and 20). The additional desalting step performed after IEX-HPLC purification could explain the difference between the conjugation efficacies and the recovery yields. Moreover, in HPLC chromatograms, minor peaks with shorter retention times are noteworthy (Figure 2a, Figures S12-S15). These peaks were assigned to shorter RNA sequences corresponding to some chemical degradations of RNA probably due to the excess of small molecules at high concentration $(100 \mathrm{mM})$ in the reaction mixture. To check this hypothesis, we monitored the stability of the unmodified RNA siEF-4S in the presence of small molecules 10-13 by IEX-HPLC (Figure S19). After $24 \mathrm{~h}$ incubation, the peaks corresponding to siEF-4S mostly decreased in the presence of 1 -

Table 2: Synthesis and data for RNA-small molecules conjugates 17-24 linked by a disulfide linkage

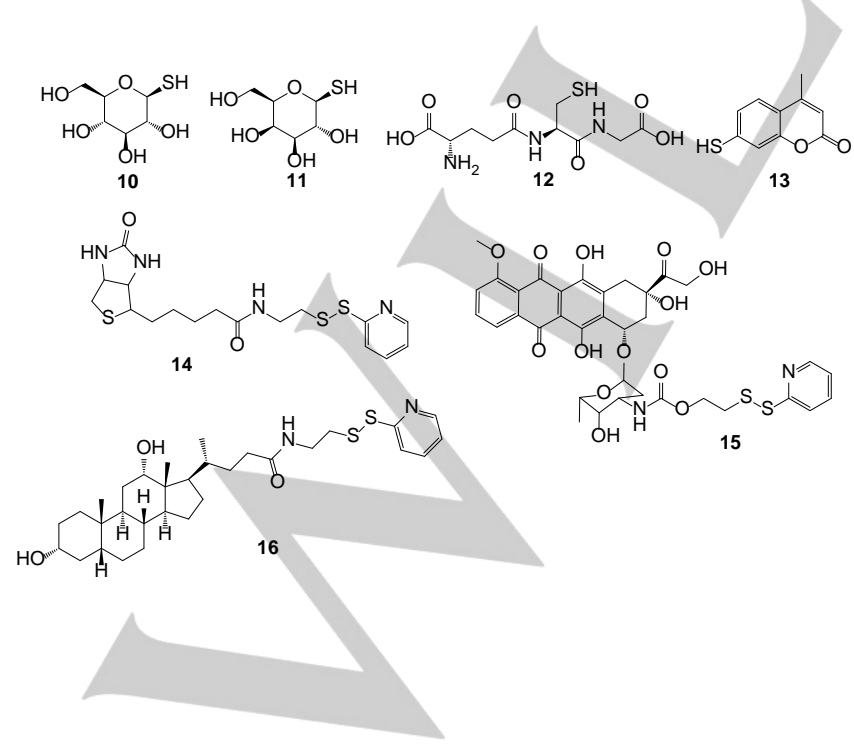

thio- $\beta$-D-glucose 10 (33\%), 1-thio- $\beta$-D-galactose 11 (54\%), 7mercapto-4-methylcoumarin $13(6 \%)$, respectively whereas siEF$4 \mathrm{~S}$ remained more stable (89\%) in the presence of glutathione 12. 


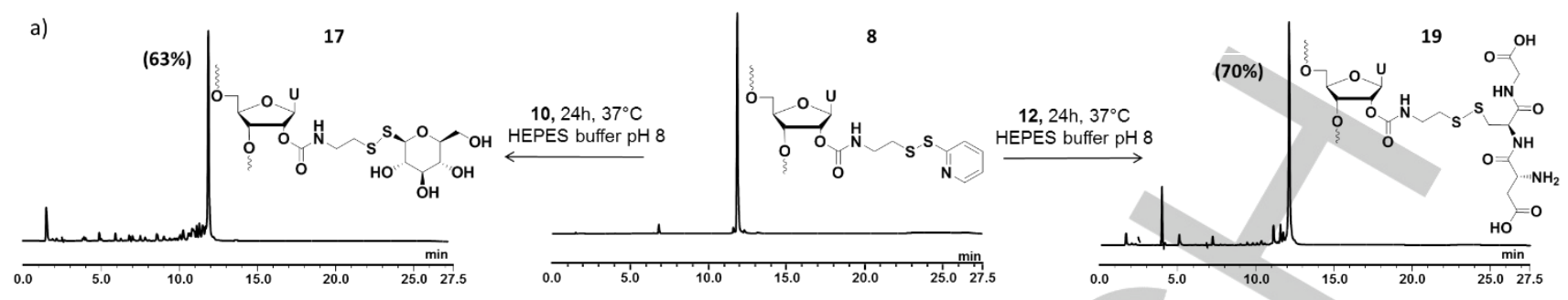

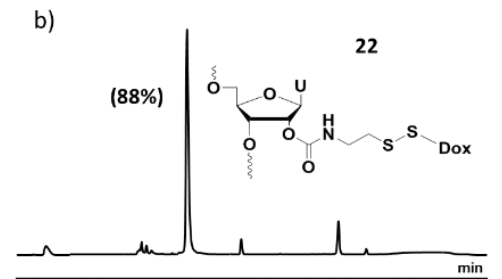

\begin{tabular}{llllllllllllll}
\hline 0.0 & 1.3 & 2.5 & 3.8 & 5.0 & 6.3 & 7.5 & 8.8 & 10.0 & 11.3 & 12.5 & 13.8 \\
\hline
\end{tabular}
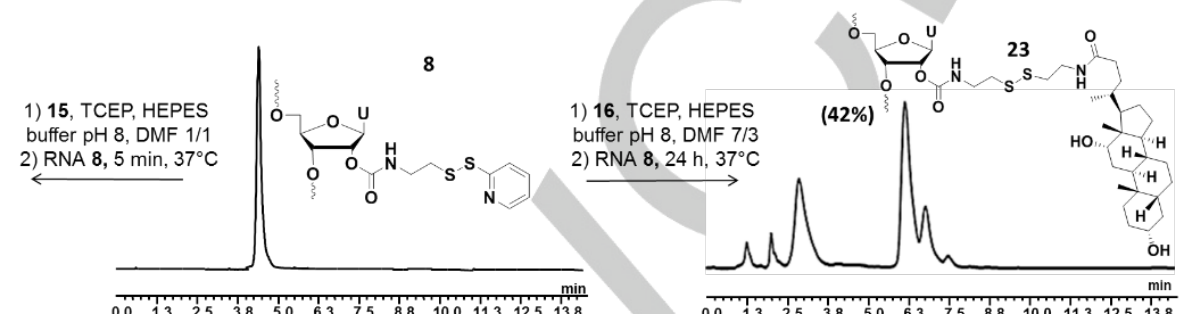

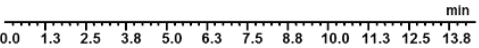




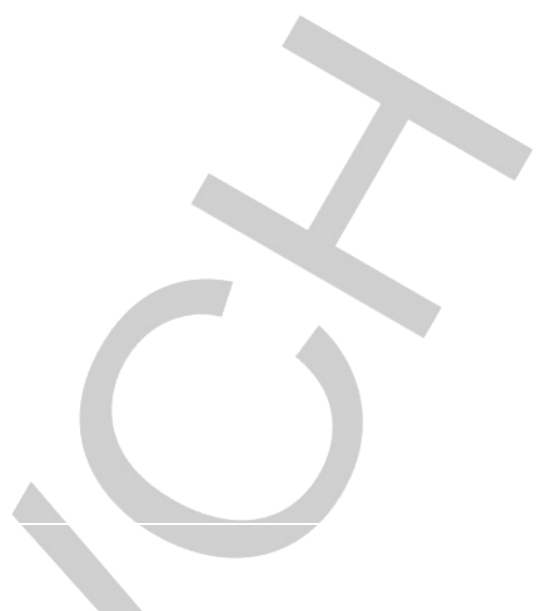

Figure 2. a) IEX-HPLC profiles of solution phase conjugation of RNA 8 with 1-thio- $\beta$-D-glucose 10 to give RNA-glucose conjugate 17 (left panel) and glutathione 12 to give RNA-glutathione conjugate 19 (right panel) upon method A. b) RP-HPLC profiles of solution phase conjugation of RNA 8 (top panel) with Dox-SS-py derivative 15 (left panel) and deoxycholic acid derivative 16 (right panel) upon method B to afford RNA conjugates 22 and 23, respectively.

These results confirm that high concentration of 1-thio- $\beta$-Dglucose 10, 1-thio- $\beta$-D-galactose 11 or 7-mercapto-4methylcoumarin 13 causes some RNA degradation and might partially explain the low recovery yields.

The conjugation with more hydrophobic molecules was also evaluated using an alternative method $B$. In this case, the pyridyldisulfanyl derivatives of biotin and deoxycholic acid 14 and 16, respectively, have been synthesized from biotin and deoxycholic acid that are not commercially available with a thiol function (Schemes S1-S2). ${ }^{[20]}$ Likewise, the doxorubicin pyridyldisulfanyl derivative (Dox-SS-Py) 15 was prepared following a described protocol. ${ }^{[21]}$ The coupling of the pyridyldisulfanyl derivatives 14,15 and 16 has been achieved upon method B (Table 2). First, they were treated with tris(2carboxyethyl) phosphine (TCEP) in a mixture of HEPES buffer and DMF for $2 \mathrm{~h}$ to generate a thiol function. Then, this solution was directly added to the dry 2'-O-PySSEC RNA 8 upon stirring. The reaction was performed at $37^{\circ} \mathrm{C}$ for $24 \mathrm{~h}$ and monitored by IEX-HPLC for conjugate 21 (Figure S16) and RP-HPLC for 22 and 23 to optimize chromatographic separation (Figures 2b, S17-S18) After $24 \mathrm{~h}$, the crude RNA conjugates were purified by IEX-HPLC or RP-HPLC and characterized by MALDI-TOF mass spectrometry. When treating RNA 8 with Dox-SS-Py 15, some RNA degradations were observed within $24 \mathrm{~h}$, the yield was improved by reducing the coupling time. Indeed, after $5 \mathrm{~min}$ incubation with Dox-SS-Py 15, the peak corresponding to RNA 8 in the HPLC chromatogram has totally disappeared and the newly major peak was assigned to RNA conjugate $\mathbf{2 2}$ with satisfactory conjugation and recovery yields ( $88 \%$ and $63 \%$, respectively) (Figure $2 \mathrm{~b}$ left panel, Table 2). A similar estimated conjugation yield (89\%) was obtained for RNA conjugate $\mathbf{2 1}$ with biotin after $24 \mathrm{~h}$ coupling time (Table 2 ). In contrast, RNA conjugate 23 with deoxycholic acid was formed with lower conjugation yields (42\%) after $24 \mathrm{~h}$ reaction (Figure $2 \mathrm{~b}$, right panel). The steric hindrance of deoxycholic acid derivative could partially explain this low yield.
Moreover, supplementary peaks were also detectable in the HPLC chromatogram, probably due to the chemical degradation of RNA caused by high concentration of deoxycholic acid derivative 16.

To check this hypothesis, the stability of unmodified RNA siEF$4 S$ in the presence of pyridyldisulfanyl derivatives 14,15 and 16 was monitored by IEX-HPLC. Compounds 14, 15 and 16 were treated with TCEP in a mixture of HEPES buffer and DMF for $2 \mathrm{~h}$ and were added to siEF-4S. After $24 \mathrm{~h}$ and $48 \mathrm{~h}$ incubation, siEF$\mathbf{4 S}$ remained nearly intact in the presence of 14, 15 and 16 (Figure S20). Nevertheless, after 72 h, siEF-4S was slightly hydrolyzed in the presence of biotin derivative $\mathbf{1 4}$ (corresponding peak at $87 \%$ ) and more significantly in the presence of doxorubicin (corresponding peak at 62\%) whereas siEF-4S was totally degraded in the presence of deoxycholic acid derivative 16. The steric hindrance of $\mathbf{1 6}$ combined to chemical degradation of RNA might explain the lower conjugation efficiency and recovery yield for RNA-deoxycholic acid conjugate 23.

In order to synthesize a multi-conjugated RNA, we explored the conjugation reaction between Dox-SS-Py derivative 15 and RNA 9 bearing 2'-O-PySSEC modifications on two distinct ribonucleotides. Indeed, combination therapy of cancer using two drugs with different mechanisms of action (RNAi and chemotherapy with Dox) has aroused great interest for many years. Both drugs exhibit an individual biological activity in a synergistic manner in cancer cells and can overcome multidrug resistance, thereby inhibiting tumor progression. Up to now, numerous attempts have been made to co-deliver anticancer drugs and siRNA into cancer cells using a wide variety of nanocarriers (nanoparticles, micelles, liposomes). ${ }^{[22]}$

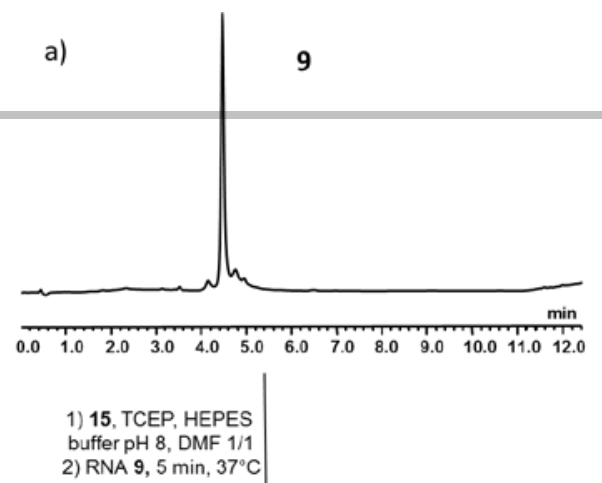


Figure 3. HPLC profiles of solution phase conjugation of RNA 9 with Dox-SSPy derivative 15. RP-HPLC profiles of pure RNA 9 (panel a) and crude double DOX RNA conjugate 24 (panel b). Panel c: IEX-chromatogram and MALDI-TOF mass spectrum of pure RNA conjugate 24

Here, the disulfide-linked Dox-siRNA conjugates were designed to simultaneously deliver both molecules to cancer cells and lipophilic Dox can be expected to increase siRNA uptake.

The double Dox-conjugation with RNA 9 was performed in the same conditions as for the preparation of single Dox-conjugate 22 (Table 2). After $5 \mathrm{~min}, \mathrm{HPLC}$ analysis of the crude product showed one major peak (71\%) corresponding to the desired conjugate 24 (Figure 3b). After purification, double Dox-RNA 24 was obtained with high purity in acceptable yield (38\%) (Figure 3c). The MALDI-TOF analysis exhibited a peak $(\mathrm{m} / \mathrm{z}=8152.9)$ assigned to 24 and a second peak $(\mathrm{m} / \mathrm{z}=7754.3)$ resulting from the mass fragmentation of Dox during analysis. As previously reported, this peak corresponds to the loss of the amino sugar moiety (loss of 398). ${ }^{[23]}$ The successful synthesis of this doubleDox RNA conjugate $\mathbf{2 4}$ lets expect that the multiple-sites conjugation should be efficient using method $B$.

Glutathione treatment. The reduction-responsive feature of the RNA-small molecule conjugates 17-23 was tested in the presence of glutathione (GSH) which is the most abundant thiol in the cytosol (up to $10 \mathrm{mM}$ ) whereas it is found at low concentration in extracellular medium.

GSH sensitivity of all the conjugates 17-23 were evaluated with $5.6 \mathrm{mM} \mathrm{GSH}$ in HEPES buffer $(\mathrm{pH}$ 8) by MALDI-TOF mass spectrometry. After 5 min incubation, as shown in Figure 4, the peak corresponding to the initial RNA-biotin conjugate $21(\mathrm{~m} / \mathrm{z}$ 7061.8) has disappeared and the peak at $\mathrm{m} / \mathrm{z} 6764.2$ was assigned to the intermediate thiol resulting from the disulfide cleavage.

A new peak at $\mathrm{m} / \mathrm{z} 7066.6$ corresponding to the conjugate RNAGSH 19 is noteworthy in the MS spectrum after $1.5 \mathrm{~h}$ incubation. Indeed, the released thiol has probably attacked the disulfide bond of the glutathione disulfide (GSSG), produced upon the spontaneous oxidation of GSH. After $6 \mathrm{~h}$, RNA-GSH 19 was the sole compound detected in mass spectrometry and remained perfectly stable after $24 \mathrm{~h}$. The same result was observed for all RNA-small molecule conjugates (Figures S21-S26). Moreover, after $6 \mathrm{~h}$, mass spectra of RNA conjugates 17, 20 and 23 showed important RNA degradations attesting the RNA sensitivity to 1thio- $\beta$-D-glucose, 7-mercapto-4-methylcoumarin and deoxycholic acid derivatives (Figures S21, S24, S26). These results evidence that the disulfide bond is rapidly cleaved in the presence of GSH leading to a thiol derivative that is very reactive to conjugation with other disulfide-containing molecules, nevertheless the small molecules are released.

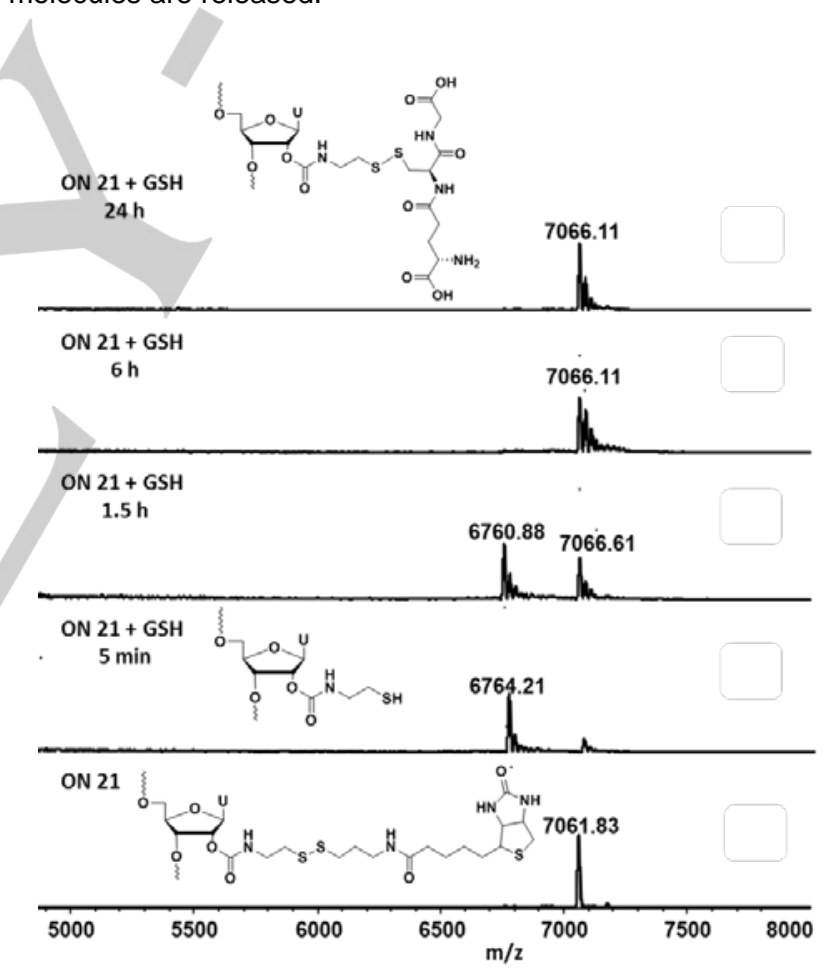

Figure 4. MALDI-TOF MS spectra of RNA-biotin conjugate 21 incubated in the presence of $5.6 \mathrm{mM} \mathrm{GSH}$ in HEPES buffer $(\mathrm{pH} 8)$ at $37^{\circ} \mathrm{C}$, over $24 \mathrm{~h}$

\section{Conclusions}


In this work, a large variety of small molecules were successfully conjugated to RNA using a disulfide linker attached to a 2'-OH uridine via a carbamate function. The 2'-functionalization of RNA was achieved through the 2'-O-N[(acetylthio)-ethylcarbamoyl] uridine phosphoramidite, synthesized in 6 steps with $51 \%$ overall yield. Then, the thiol precursor in RNA was activated on solid support with a pyridyldisulfanyl group allowing subsequent thioldisulfide exchange reaction in solution with diverse small molecules bearing a thiol function. Moreover, the successful preparation of a RNA bearing two Dox molecules attests the great potential of this method for conjugation at multiple and welldefined sites. The rapid cleavage of the disulfide bridge upon 5.6 $\mathrm{mM}$ GSH shows that such RNA conjugates will be responsive to the reducing environment of the intracellular medium. The smallmolecules will be released with a wide field of applications such as cell-imaging, in vitro detection or drug delivery. Particularly, in cancer therapy a co-delivery system based on multiple doxorubicin attached to siRNA via a disulfide bond might be envisaged to boost the anticancer activity and overcome multidrug resistance.

\section{Experimental Section}

General Methods. Pyridine, triethylamine and DIEA were distilled over calcium hydride and methanol was distilled over sodium. All other solvents and reagents were purchased from commercial suppliers and were used without further purification. Thin-layer chromatography (TLC) analyses were carried out on silica plate $60 \mathrm{~F}_{254}$. Purifications by column chromatography were performed using 0.040-0.063 $\mathrm{mm}$ silica from Merck. NMR experiments were recorded on a Bruker 400 spectrometer at $20^{\circ} \mathrm{C}$. HRMS analyses were obtained with electrospray ionization (ESI) in positive mode on a Q-TOF Micromass spectrometer. RNAs were synthesized using an automated DNA synthesizer (Applied Biosystems 394). Crude RNAs and conjugates 8-21 were analyzed and purified by IEX-HPLC Dionex DNAPac ${ }^{\circ}$ PA100, 4 × $250 \mathrm{~mm}$ for analysis or $9 \times 250$ for semi-preparative purpose. The following HPLC solvent system was used: $5 \% \mathrm{CH}_{3} \mathrm{CN}$ in $25 \mathrm{mM}$ Tris- $\mathrm{HCl} \mathrm{pH} 8$ (buffer A), $5 \% \mathrm{CH}_{3} \mathrm{CN}$ containing $400 \mathrm{mM} \mathrm{NaClO}_{4}$ in $25 \mathrm{mM}$ Tris- $\mathrm{HCl} \mathrm{pH} 8$ (buffer $\mathrm{B}$ ). Flow rates were $1.0 \mathrm{~mL} / \mathrm{min}$ for analysis or $4 \mathrm{~mL} / \mathrm{min}$ for semi-preparative purpose; UV detection was performed at $260 \mathrm{~nm}$. Crude RNA conjugates 22-24 were analyzed and purified by RP-HPLC (Thermo Scientific Accucore aQ $\mathrm{C}_{18} 2.6 \mu \mathrm{m}, 2.1 \times 50 \mathrm{~mm}$ ). The following HPLC solvent systems were used: $1 \% \mathrm{CH}_{3} \mathrm{CN}$ in $12.5 \mathrm{mM}$ TEAAc (buffer $\mathrm{A}$ ), $80 \% \mathrm{CH}_{3} \mathrm{CN}$ in $12.5 \mathrm{mM}$ TEEAc (buffer B). Flow rates were $1.9 \mathrm{~mL} / \mathrm{min}$. UV detection was performed at $260 \mathrm{~nm}$. MALDI-TOF mass spectra were recorded using a Shimadzu AXIMA Assurance spectrometer equipped with an $\mathrm{N}_{2}$ laser $(337 \mathrm{~nm}$ ) (Shimadzu, Japan) using 2,1,1-trihydroxyacetophenone as a saturated solution in a mixture of acetonitrile/0.1 M ammonium citrate solution (1:1, $\mathrm{v} / \mathrm{v}$ ) for the matrix. Analytical samples were mixed with the matrix in the 1:5 (v/v) ratio, crystallized on a 384-well stainless steel plate and analyzed. UV quantitation of RNAs was performed using a Varian Cary 300 Bio UV/Visible spectrometer by measuring absorbance at $260 \mathrm{~nm}$ and at 481 $\mathrm{nm}$ for RNA conjugates 22 and 24 . Lyophilized RNAs were stored at $-20^{\circ} \mathrm{C}$ for several months without any degradation.

2'-O-(4-nitrophenoxycarbonyl)-3',5'-O-(1,1,3,3-

tetraisopropyldisiloxane-1,3-diyl) uridine (2). A solution of 3',5'-O- (tetraisopropyldisiloxane-1, 3-diyl) uridine 1 (5.00 g, $10.28 \mathrm{mmol}, 1.00$ equiv) in dry toluene $(100 \mathrm{~mL})$ was treated under argon with dry pyridine (0.82 mL, $10.28 \mathrm{mmol}, 1.00$ equiv) and 4-nitrophenyl chloroformate (2.38 $\mathrm{g}, 11.82 \mathrm{mmol}, 1.15$ equiv). The mixture was stirred for $3 \mathrm{~h}$ at room temperature. Then, dry pyridine $(0.15 \mathrm{~mL}, 2.06 \mathrm{mmol}, 0.20$ equiv) and 4nitrophenyl chloroformate $(0.475 \mathrm{~g}, 2.06 \mathrm{mmol}, 0.20$ equiv) were added. After stirring at room temperature for $2 \mathrm{~h}$, the mixture was diluted in ethyl acetate and washed with water. The aqueous layer was then extracted with ethyl acetate. The organic layer was washed with brine and dried over $\mathrm{Na}_{2} \mathrm{SO}_{4}$. The solvent was evaporated under reduced pressure. The crude material was purified by silica gel column chromatography with cyclohexane/ethyl acetate (70/30). The desired compound 2 was obtained as white foam (5.4 g, 8.2 mmol, $81 \quad \%)$. ${ }^{1} \mathrm{H} \mathrm{NMR}\left(\mathrm{CDCl}_{3}, 400 \mathrm{MHz}\right) \delta \mathrm{ppm}: 9.14(\mathrm{~s}, 1 \mathrm{H}, \mathrm{NH}), 8.28(\mathrm{~d}, \mathrm{~J}=8.0 \mathrm{~Hz}$, $2 \mathrm{H}, \mathrm{Ph}), 7.75\left(\mathrm{~d}, \mathrm{~J}=8.0 \mathrm{~Hz}, 1, \mathrm{H}_{6}\right), 7.38(\mathrm{~d}, \mathrm{~J}=8.0 \mathrm{~Hz}, 2 \mathrm{H}, \mathrm{Ph}), 5.94$ (s, $\left.1 \mathrm{H}, \mathrm{H}_{1^{\prime}}\right), 5.74\left(\mathrm{~d}, \mathrm{~J}=8.4 \mathrm{~Hz}, 1 \mathrm{H}, \mathrm{H}_{5}\right), 5.32\left(\mathrm{~d}, \mathrm{~J}=9.2 \mathrm{~Hz}, 1 \mathrm{H}, \mathrm{H}_{2}\right)^{\prime}, 4.47$ (dd, J= 9.2 Hz, J=3.6 Hz, $\left.1 \mathrm{H}, \mathrm{H}_{3^{\prime}}\right), 4.26\left(\mathrm{~d}, \mathrm{~J}=10.0 \mathrm{~Hz}, 1 \mathrm{H}, \mathrm{H}_{5}{ }^{\prime}\right), 4.11$ (d, J = 3.6 Hz, $\left.\left.1 \mathrm{H}, \mathrm{H}_{4}\right)^{\prime}\right), 4.02$ (d, J = 10.2 Hz, $1 \mathrm{H}, \mathrm{H}_{5}^{\prime}$ ), 1.10-0.98 (m, 28

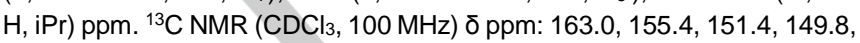
145.5, 139.0, 125.4, 121.7, 102.4, 88.0, 82.0, 80.2, 67.8, 59.1, 17.4 - 16.7 (8 C), 13.8 - 12.5 (4 C) ppm. HRMS $\left(\mathrm{ESI}^{+}\right)$: $\mathrm{m} / \mathrm{z}$ calcd. for $\mathrm{C}_{28} \mathrm{H}_{42} \mathrm{~N}_{3} \mathrm{O}_{11} \mathrm{Si}_{2}$ : $652.2358[\mathrm{M}+\mathrm{H}]^{+}$, found 652.2365 .

2'-O-[N-(2-bromoethylcarbamoyl)]-3',5'-O-(1,1,3,3-

tetraisopropyldisiloxane-1,3-diyl) uridine (3). A solution of compound 2 $(2.38 \mathrm{~g}, 3.65 \mathrm{mmol}, 1.00$ equiv) in dry pyridine $(36.5 \mathrm{~mL})$ was treated under argon with 2-bromoethylamine hydrobromide $(0.897 \mathrm{~g}, 4.38 \mathrm{mmol}, 1.2$ equiv) and dry triethylamine $(0.5 \mathrm{~mL}, 7.3 \mathrm{mmol}, 2$ equiv). After stirring at room temperature for $4 \mathrm{~h}$, the mixture was diluted in ethyl acetate and washed with water. The aqueous layer was then extracted with ethyl acetate. The combined organic extracts were washed with brine and dried over $\mathrm{Na}_{2} \mathrm{SO}_{4}$. The solvent was removed under reduced pressure. The crude material was purified by silica gel column chromatography with a step gradient of dichloromethane and ethyl acetate (10-30\%). The desired compound 3 was obtained as white foam $(2.27 \mathrm{~g}, 3.57 \mathrm{mmol}, 98 \%) .{ }^{1} \mathrm{H}$ NMR $\left(\mathrm{CDCl}_{3}, 400 \mathrm{MHz}\right) \delta \mathrm{ppm}: 9.23(\mathrm{~s}, 1 \mathrm{H}, \mathrm{NH}), 7.65(\mathrm{~d}, \mathrm{~J}=4.1 \mathrm{~Hz}, 1 \mathrm{H}$, $\left.\mathrm{H}_{6}\right), 5.83\left(\mathrm{~s}, 1 \mathrm{H}, \mathrm{H}_{1}\right), 5.69\left(\mathrm{dd}, \mathrm{J}=4.1 \mathrm{~Hz}, \mathrm{~J}=1.1 \mathrm{~Hz}, 1 \mathrm{H}, \mathrm{H}_{5}\right), 5.67(\mathrm{t}, \mathrm{J}$ $=5.5 \mathrm{~Hz}, 1 \mathrm{H}, \mathrm{NH}), 5.27\left(\mathrm{~d}, \mathrm{~J}=5.1 \mathrm{~Hz}, 1 \mathrm{H}, \mathrm{H}_{2}\right), 4.35(\mathrm{dd}, \mathrm{J}=5.1 \mathrm{~Hz}, \mathrm{~J}=$ $\left.3.1 \mathrm{~Hz}, 1 \mathrm{H}, \mathrm{H}_{3^{\prime}}\right), 4.19\left(\mathrm{~d}, \mathrm{~J}=7.1 \mathrm{~Hz}, 1 \mathrm{H}, \mathrm{H}_{5}{ }^{\prime}\right), 3.99-3.96\left(\mathrm{~m}, 2 \mathrm{H}, \mathrm{H}_{5^{\prime}}, \mathrm{H}_{4^{\prime}}\right)$, 3.66-3.51. (m, $\left.2 \mathrm{H}, \mathrm{CH}_{2}\right), 3.45\left(\mathrm{t}, \mathrm{J}=5.3 \mathrm{~Hz}, 2 \mathrm{H}, \mathrm{CH}_{2}\right), 1.08-0.99(\mathrm{~m}, 28$ $\mathrm{H}$, iPr). ${ }^{13} \mathrm{C} \mathrm{NMR}\left(\mathrm{CDCl}_{3}, 100 \mathrm{MHz}\right) \delta \mathrm{ppm}: 163.2,154.4,149.7,139.3$, 102.2, 88.5, 82.1, 76.1, 67.9, 59.7, 42.8, 32.2, 16.7-17.4 (8 C), 12.5-13.4 (4 C). HRMS $\left(\mathrm{ESI}^{+}\right)$: $\mathrm{m} / \mathrm{z}$ calcd for $\mathrm{C}_{24} \mathrm{H}_{\mathrm{h} 42} \mathrm{BrN}_{3} \mathrm{O}_{8} \mathrm{Si}_{2}[\mathrm{M}+\mathrm{H}]^{+}: 636.1772$, found 636.1779 .

\section{2'-O-[N-(2-acetylthio)-ethylcarbamoyl]-3',5'-O-(1,1,3,3}

tetraisopropyldisiloxane-1,3-diyl) uridine (4). Under argon, compound 3 (4.2 g, $6.6 \mathrm{mmol}, 1.00$ equiv) was dissolved in dry acetonitrile (132 mL) at $40^{\circ} \mathrm{C}$. The solution was treated with potassium thioacetate $(1.12 \mathrm{~g}, 9.9$ mmol, 1.5 equiv) and 18-crown-6 (0.871 g, $3.3 \mathrm{mmol}, 0.5$ equiv). After stirring at room temperature overnight, the mixture was diluted in ethyl acetate and washed with water. The aqueous layer was then extracted with ethyl acetate. The combined organic extracts were washed with brine and dried over $\mathrm{Na}_{2} \mathrm{SO}_{4}$. The solvent was evaporated under reduced pressure. The crude material was purified by silica gel column chromatography with a step gradient of dichloromethane and ethyl acetate (0-20\%). The desired compound 4 was obtained as white foam (3.36 g, $5.32 \mathrm{mmol}, 80 \%) .{ }^{1} \mathrm{H}$ NMR $\left(\mathrm{CDCl}_{3}, 400 \mathrm{MHz}\right) \delta \mathrm{ppm}: 8.68(\mathrm{~s}, 1 \mathrm{H}, \mathrm{NH})$, $7.63\left(\mathrm{~d}, \mathrm{~J}=8.4 \mathrm{~Hz}, 1 \mathrm{H}, \mathrm{H}_{6}\right), 5.80\left(\mathrm{~s}, 1 \mathrm{H}, \mathrm{H}_{1}\right), 5.69\left(\mathrm{~d}, \mathrm{~J}=8.0 \mathrm{~Hz}, 1 \mathrm{H}, \mathrm{H}_{5}\right)$, $5.25\left(\mathrm{~d}, \mathrm{~J}=4.4 \mathrm{~Hz}, 1 \mathrm{H}, \mathrm{H}_{2^{\prime}}\right), 5.14(\mathrm{~s}, 1 \mathrm{H}, N H), 4.36(\mathrm{dd}, \mathrm{J}=7.8 \mathrm{~Hz}, \mathrm{~J}=$ $\left.5.4 \mathrm{~Hz}, 1 \mathrm{H}, \mathrm{H}_{3^{\prime}}\right), 4.18\left(\mathrm{~d}, \mathrm{~J}=11.1 \mathrm{~Hz}, 1 \mathrm{H}, \mathrm{H}_{5}{ }^{\prime}\right), 4.00-3.95\left(\mathrm{~m}, 2 \mathrm{H}, \mathrm{H}_{5}\right.$, $\left.\mathrm{H}_{4}{ }^{\prime}\right)$, 3.37-3.35 (m, $\left.2 \mathrm{H} \mathrm{CH}_{2}\right), 3.00\left(\mathrm{t}, \mathrm{J}=6.1 \mathrm{~Hz}, 2 \mathrm{H}, \mathrm{CH}_{2}\right), 2.34(\mathrm{~s}, 3 \mathrm{H}$, $\left.\mathrm{CH}_{3}\right), 1.08-0.95(\mathrm{~m}, 28 \mathrm{H}, \mathrm{iPr}) .{ }^{13} \mathrm{C} \mathrm{NMR}\left(\mathrm{CDCl}_{3}, 100 \mathrm{MHz}\right) \delta \mathrm{ppm}: 195.8$, $162.8,154.5,149.5,139.5,102.2$, 88.7, 82.1, 75.3, 68.0, 53.4, 40.9, 30.6- 
30.9, 29.6, 16.0 - 17.4 (8C), 12.6 - 13.4 (4C). HRMS (ESI $\left.{ }^{+}\right): \mathrm{m} / \mathrm{z}$ calcd for $\mathrm{C}_{26} \mathrm{H}_{46} \mathrm{~N}_{4} \mathrm{O}_{8} \mathrm{SSi}_{2}[\mathrm{M}+\mathrm{H}]^{+}:$632.2493, found 632.2493 .

2'-O-[N-(2-acetylthio)-ethylcarbamoyl] uridine (5). Under argon, compound 4 ( $3.36 \mathrm{~g}, 5.3 \mathrm{mmol}, 1.00$ equiv) was dissolved in dry THF (74.5 $\mathrm{mL}$ ). The solution was treated dropwise with triethylamine trihydrofluoride (1.7 $\mathrm{mL}, 10.6 \mathrm{mmol}, 2$ equiv). After stirring $4 \mathrm{~h}$ at room temperature, the deprotection was complete and the reaction mixture was treated with triethylammoniumacetate buffer $(2 \mathrm{M}, \mathrm{pH} 7)$, then co-evaporated with water and acetonitrile. The crude material was purified by silica gel column chromatography with dichloromethane and methanol (95/5). The desired compound 5 was obtained as white foam $(1.9 \mathrm{~g}, 4.88 \mathrm{mmol}, 92 \%) .{ }^{1} \mathrm{H}$ NMR (DMSO-d, $400 \mathrm{MHz}) \delta$ ppm: $11.32(\mathrm{~s}, 1 \mathrm{H}, \mathrm{NH}), 7.89(\mathrm{~d}, \mathrm{~J}=8.1 \mathrm{~Hz}$, $\left.1 \mathrm{H}, \mathrm{H}_{6}\right), 7.50(\mathrm{t}, \mathrm{J}=6.0 \mathrm{~Hz}, 1 \mathrm{H}, \mathrm{NH}), 5.97\left(\mathrm{~d}, \mathrm{~J}=6.3 \mathrm{~Hz}, 1 \mathrm{H}, \mathrm{H}_{1^{\prime}}\right), 5.66$ $\left(\mathrm{d}, \mathrm{J}=8.2 \mathrm{~Hz}, 1 \mathrm{H}, \mathrm{H}_{5}\right), 5.47(\mathrm{t}, \mathrm{J}=5.2 \mathrm{~Hz}, 1 \mathrm{H}, \mathrm{OH}), 5.18(\mathrm{t}, \mathrm{J}=4.6 \mathrm{~Hz}$, $1 \mathrm{H}, \mathrm{H}_{2}$ ), $5.02\left(\mathrm{t}, \mathrm{J}=5.7 \mathrm{~Hz}, \mathrm{~J}=5.1 \mathrm{~Hz}, 1 \mathrm{H}, \mathrm{H}_{3^{\prime}}\right), 4.19$ (dd, J = 8.5 Hz, J = $\left.4.9 \mathrm{~Hz}, 1 \mathrm{H}, \mathrm{H}_{4}\right), 3.88(\mathrm{~d}, \mathrm{~J}=3.0 \mathrm{~Hz}, 1 \mathrm{H}, \mathrm{OH}), 3.65-3.54\left(\mathrm{~m}, 2 \mathrm{H}, \mathrm{H}_{5}{ }^{+}+\right.$ $\mathrm{H}_{5 "}$ ), 3.25-3.09 (m, $\left.2 \mathrm{H}, \mathrm{CH}_{2}\right), 2.94-2.84\left(\mathrm{~m}, 2 \mathrm{H}, \mathrm{CH}_{2}\right), 2.31\left(\mathrm{~s}, 3 \mathrm{H}, \mathrm{CH}_{3}\right)$. ${ }^{13} \mathrm{C}$ NMR (DMSO-d, $\left.100 \mathrm{MHz}\right) \delta \mathrm{ppm}: 195.6,163.5,155.6,151.0,141.1$, 102.6, 86.2, 85.9, 75.2, 69.4, 61.4, 40.9, 31.0, 28.8. HRMS $\left(E S I^{+}\right): \mathrm{m} / \mathrm{z}$ calcd for $\mathrm{C}_{14} \mathrm{H}_{19} \mathrm{~N}_{3} \mathrm{O}_{8} \mathrm{~S}[\mathrm{M}+\mathrm{H}]^{+}:$390.0971, found 390.0972 .

\section{2'-O-[N-(2-acetylthio)-ethylcarbamoyl]-5'-O-(4,4'-dimethoxytrityl)}

uridine (6). Compound 5 (0.532 g, $1.37 \mathrm{mmol}, 1$ equiv) was dried for $24 \mathrm{~h}$ under reduced pressure, then was dissolved under argon in dry pyridine $(2.6 \mathrm{~mL})$ at room temperature. After complete dissolution, dry DCM (13.7 $\mathrm{mL}$ ) was added. The solution was treated with $\mathrm{N}, \mathrm{N}$-diisopropylethylamine (DIEA) (263 $\mu \mathrm{L}, 1.51 \mathrm{mmol}, 1.1$ equiv) and dimethoxytrityl chloride (DMTrCl) (559 mg, 1.65 mmol, 1.2 equiv) added in small portions over $1 \mathrm{~h}$. After $2 \mathrm{~h}$ and $6 \mathrm{~h}$, DIEA and DMTrCl ( 0.5 and 0.2 equiv respectively) were added to the reaction. Completion was reached after $7 \mathrm{~h}$, the mixture was diluted in $\mathrm{DCM}$ and poured into saturated $\mathrm{NaHCO}_{3}$ solution. The aqueous layer was then extracted with DCM. The combined organic extracts were washed with brine and dried over $\mathrm{Na}_{2} \mathrm{SO}_{4}$. The solvent was removed under reduced pressure. The crude material was purified by silica gel column chromatography with DCM and pyridine (99/1), then DCM with methanol (1-5 \%). The desired compound 6 was obtained as pale yellow foam (980 mg, 1.34 mmol, $98 \%)$. ${ }^{1} \mathrm{H}$ NMR ( $\left.\mathrm{CDCl}_{3}, 400 \mathrm{MHz}\right): \delta$ ppm: $9.36(\mathrm{~s}, 1 \mathrm{H}$ $N H), 7.75\left(\mathrm{~d}, \mathrm{~J}=8.2 \mathrm{~Hz}, 1 \mathrm{H}, \mathrm{H}_{6}\right), 7.40-7.16\left(\mathrm{~m}, 9 \mathrm{H}, \mathrm{H}_{\mathrm{Ar}}\right), 6.84(\mathrm{~d}, \mathrm{~J}=8.9$ $\left.\mathrm{Hz}, 4 \mathrm{H}, \mathrm{H}_{\mathrm{Ar}}\right), 6.17\left(\mathrm{~d}, \mathrm{~J}=5.1 \mathrm{~Hz}, 1 \mathrm{H}, \mathrm{H}_{1}\right), 5.80(\mathrm{t}, J=6.1 \mathrm{~Hz}, 1 \mathrm{H}, N H)$, 5.34 (dd, $\left.J=8 \mathrm{~Hz}, J=1.2 \mathrm{~Hz}, 1 \mathrm{H}, \mathrm{H}_{5}\right), 5.24\left(\mathrm{t}, \mathrm{J}=5.1 \mathrm{~Hz}, 1 \mathrm{H}, \mathrm{H}_{2}\right), 4.67$ $\left(\mathrm{dd}, \mathrm{J}=7.6 \mathrm{~Hz}, \mathrm{~J}=4.0 \mathrm{~Hz}, 1 \mathrm{H}, \mathrm{H}_{3^{\prime}}\right), 4.17\left(\mathrm{~d}, \mathrm{~J}=3.1 \mathrm{~Hz}, 1 \mathrm{H}, \mathrm{H}_{4}\right), 3.79$ (s, $\left.6 \mathrm{H}, \mathrm{OCH}_{3}\right), 3.57\left(\mathrm{~m}, 1 \mathrm{H}, \mathrm{H}_{5^{\prime}}\right), 3.57-3.48\left(\mathrm{~m}, 2 \mathrm{H}, \mathrm{H}_{5}{ }^{\prime}+\mathrm{HCH}\right), 3.25-2.89$ $\left(\mathrm{m}, 1 \mathrm{H}+2 \mathrm{H}, \mathrm{HCH}+\mathrm{CH}_{2}\right), 2.15\left(\mathrm{~s}, 3 \mathrm{H}, \mathrm{CH}_{3}\right) \cdot{ }^{13} \mathrm{C} \mathrm{NMR}\left(\mathrm{CDCl}_{3}, 100 \mathrm{MHz}\right)$ $\delta$ ppm: 196.9, 163.3, 158.7, 155.4, 150.7, 144.2, 140.2, 137.9, 135.9, 135.0, 130.2, 130.2, 130.0, 129.1, 129.1, 128.2, 128.2, 128.1, 128.1, 127.2 $125.3,113.4,113.3,102.8,87.2,86.0,84.1,70.3,62.8,55.3,55.3,41.2$, 28.8, 21.5. HRMS $\left(\mathrm{ESI}^{+}\right): \mathrm{m} / \mathrm{z}$ calcd for $\mathrm{C}_{35} \mathrm{H}_{38} \mathrm{~N}_{3} \mathrm{O}_{10} \mathrm{~S}[\mathrm{M}+\mathrm{H}]^{+}: 692.2200$, found 692.2283 .

\section{2'-O-[N-(2-acetylthio)-ethylcarbamoyl]-3'-O-(2-cyanoethyl- $N, N$ -} diisopropylphosphoramidite)-5'-O-(4,4'-dimethoxytrityl) uridine 7 Under argon, compound 6 ( $0.850 \mathrm{~g}, 1.23 \mathrm{mmol}, 1$ equiv) was dissolved in anhydrous $\mathrm{CH}_{2} \mathrm{Cl}_{2}(10 \mathrm{~mL})$ previously passed through an alumina column. A mixture of DIEA (386 $\mu \mathrm{L}, 2.21 \mathrm{mmol}, 1.8$ equiv) and 2-cyanoethyl $N, N$ diisopropylchlorophosphoramidite (437 $\mu \mathrm{L}, 1.95 \mathrm{mmol}, 1.5$ equiv) in $\mathrm{CH}_{2} \mathrm{Cl}_{2}(2.3 \mathrm{~mL})$ was added dropwise. The mixture was stirred at room temperature for $1.5 \mathrm{~h}$. DIEA (129 $\mu \mathrm{L}, 0.74 \mathrm{mmol}, 0.6$ equiv) and 2cyanoethyl $\mathrm{N}, \mathrm{N}$-diisopropylchlorophosphoramidite $(137 \mu \mathrm{L}, 0.65 \mathrm{mmol}, 0.5$ equiv) in $\mathrm{CH}_{2} \mathrm{Cl}_{2}(2.3 \mathrm{~mL})$ was added dropwise, and the reaction was stirred at room temperature for $2 \mathrm{~h}$. Then, the mixture was diluted with ethyl acetate and washed with a saturated aqueous $\mathrm{NaHCO}_{3}$ solution. The aqueous phase was extracted with ethyl acetate. The combined organic layers were dried over $\mathrm{Na}_{2} \mathrm{SO}_{4}$ and evaporated under reduced pressure.
The crude residue was purified by silica gel column chromatography with an isocratic elution of $\mathrm{CH}_{2} \mathrm{Cl}_{2} /$ EtOAc (4/6) containing $1 \%$ pyridine. The desired compound 7 was obtained as a white foam. $(975 \mathrm{mg}, 1.09 \mathrm{mmol}$, $89 \%) .{ }^{1} \mathrm{H}$ NMR $\left(\mathrm{CD}_{3} \mathrm{CN}, 400 \mathrm{MHz}\right): \delta \mathrm{ppm}: 9.19(\mathrm{~s}, 1 \mathrm{H}, \mathrm{NH}), 7.75$ (d, J = 7.6 Hz, $\left.1 \mathrm{H}, \mathrm{H}_{6}\right), 7.50-7.47\left(\mathrm{~m}, 2 \mathrm{H}, \mathrm{H}_{\mathrm{Ar}}\right), 7.38-7.33\left(\mathrm{~m}, 5 \mathrm{H}, \mathrm{H}_{\mathrm{Ar}}\right), 7.23-7.18$ $\left(\mathrm{m}, 2 \mathrm{H}, \mathrm{H}_{\mathrm{Ar}}\right), 6.90$ (dd, J = 8.6 Hz, J = 3.8 Hz, $\left.4 \mathrm{H}, \mathrm{H}_{\mathrm{Ar}}\right), 6.05-5.95(\mathrm{~m}, 2 \mathrm{H}$, $\left.\mathrm{H}_{1^{\prime}}+\mathrm{NH}\right)$, 5.43-5.36 (m, $\left.2 \mathrm{H}, \mathrm{H}_{5}+\mathrm{H}_{2^{\prime}}\right), 4.68-4.59\left(\mathrm{~m}, 1 \mathrm{H}, \mathrm{H}_{3^{\prime}}\right), 4.23$ (dd, J $\left.=24.3 \mathrm{~Hz}, \mathrm{~J}=2.6 \mathrm{~Hz}, 1 \mathrm{H}, \mathrm{H}_{4}\right), 3.93-3.83\left(\mathrm{~m}, 1 \mathrm{H}, \mathrm{H}^{\prime}\right), 3.80\left(\mathrm{~s}, 3 \mathrm{H}, \mathrm{OCH}_{3}\right)$, 3.79 (s, $\left.3 \mathrm{H}, \mathrm{OCH}_{3}\right), 3.76-3.66\left(\mathrm{~m}, 1 \mathrm{H}, \mathrm{H}_{5}\right)$ ) 3.64-3.56 (m, $\left.2 \mathrm{H}, \mathrm{CH}_{2}\right), 3.41$ (dd, $\left.\mathrm{J}=15.0 \mathrm{~Hz}, \mathrm{~J}=2.8 \mathrm{~Hz}, 2 \mathrm{H}, \mathrm{CH}_{2}\right), 3.30\left(\mathrm{~h}, \mathrm{~J}=6.9 \mathrm{~Hz}, 1 \mathrm{H}, \mathrm{CH}-\left(\mathrm{CH}_{3}\right)_{2}\right)$, $3.22\left(\mathrm{~h}, \mathrm{~J}=6.8 \mathrm{~Hz}, 1 \mathrm{H}, \mathrm{CH}-\left(\mathrm{CH}_{3}\right)_{2}\right), 3.08-2.92\left(\mathrm{~m}, 2 \mathrm{H}, \mathrm{CH}_{2}\right), 2.72(\mathrm{t}, \mathrm{J}=$ $6.0 \mathrm{~Hz}, 1 \mathrm{H}, \mathrm{HCH}), 2.53(\mathrm{t}, \mathrm{J}=6.0 \mathrm{~Hz}, 1 \mathrm{H}, \mathrm{HCH}), 2.36\left(\mathrm{~s}, 3 \mathrm{H}, \mathrm{CH}_{3}\right), 1.19$ $1.06\left(\mathrm{~m}, 12 \mathrm{H}, 4 \mathrm{CH}_{3}\right) .{ }^{13} \mathrm{C} \mathrm{NMR}\left(\mathrm{CD}_{3} \mathrm{CN}, 100 \mathrm{MHz}\right) \delta$ ppm: 196.0, 163.4, $159.4,155.6,151.0,150.3,145.3,145.2,140.8,140.7,138.5,136.5,136.0$, $135.9,135.7,130.7,129.5,128.8,128.6,127.6,125.8,124.3,113.8,102.7$, $87.1,86.9,84.0,75.3,71.5,71.0,63.4,59.6,58.8,55.5,43.5,40.9,30.4$, 29.2, 24.7, 24.6, 24.5, 24.4, 21.0, 20.6. ${ }^{11} \mathrm{P}-\mathrm{NMR}\left(\mathrm{CD}_{3} \mathrm{CN}, 162 \mathrm{MHz}\right) \delta$ ppm: 149.66, 149.58. HRMS $\left(\mathrm{ESI}^{+}\right): \mathrm{m} / \mathrm{z}$ calcd for $\mathrm{C}_{44} \mathrm{H}_{54} \mathrm{~N}_{5} \mathrm{O}_{11} \mathrm{PS}[\mathrm{M}+\mathrm{H}]^{+}$: 892.3278, found 892.3345 .

Solid-phase synthesis of RNA 8 and 9. RNA oligonucleotides were synthesized using an ABI model 394 DNA/RNA synthesizer on $1 \mu \mathrm{mol}$ scale using commercial 2'-O-PivOM ribonucleosides phosphoramidites (Chemgenes) or 2'-O-[N-(acetylthioethyl)carbamoyl] uridine phosphoramidite 7 and a long chain alkylamine (LCAA) controlled-pore glass (CPG) as solid support though a succinyl linker. Oligonucleotides were assembled in TWIST $^{\mathrm{TM}}$ synthesis columns (Glen Research). Phosphoramidites were vacuum-dried prior to their dissolution in extra dry acetonitrile (Biosolve) at $0.1 \mathrm{M}$ concentration. Coupling for $180 \mathrm{~s}$ was performed with 5-benzylmercaptotetrazole (BMT, $0.3 \mathrm{M}$ ) as the activator. The oxidizing solution was $0.1 \mathrm{M}$ iodine in THF/pyridine/ $\mathrm{H}_{2} \mathrm{O}$ (78:20:2, $\mathrm{v} / \mathrm{v} / \mathrm{v}$ ) (Link Technologies). The capping step was performed with a mixture of $5 \%$ phenoxyacetic anhydride $\left(\mathrm{Pac}_{2} \mathrm{O}\right)$ in THF and $10 \% \mathrm{~N}$ methylimidazole in THF (Link Technologies). Detritylation was performed with 3\% TCA in $\mathrm{CH}_{2} \mathrm{Cl}_{2}$. After RNA assembly completion, the column was removed from the synthesizer and dried under a stream of argon.

The solid support was treated with $2 \mathrm{~mL}$ of a $0.4 \mathrm{M}$ solution of 2,2' dithiodipyridine (1000 equiv. per modification) and a $2.5 \mathrm{M}$ butylamine ( 0.5 $\mathrm{mL})$ solution in anhydrous THF $(1.5 \mathrm{~mL})$. The solution was applied to the synthesis column using two glass syringes filled with $4 \AA$ molecular sieves ( 5 beads each), and was pushed back and forth through the synthesis column for $15 \mathrm{~min}$. Then the solution was removed and the solid-support was washed with anhydrous THF followed by a 1 min flush with argon. Finally, the solid support was treated with a $30 \%$ aqueous ammonia solution for $3 \mathrm{~h}$ at $25^{\circ} \mathrm{C}$. The solution was evaporated in the presence of isopropylamine ( $13 \%$ of total volume) under reduced pressure. The residue was dissolved in $1.5 \mathrm{~mL}$ water, transferred to a $2 \mathrm{~mL}$ Eppendorfvial and lyophilized.

Analysis, purification and desalting of RNA 8 and 9. The crude RNAs were then purified by semi-preparative IEX-HPLC with a 20 min linear gradient of $0 \%$ to $60 \%$ of eluent $B$ in eluent $A$. The pure fractions of each RNA were pooled in a $100 \mathrm{~mL}$ round-bottomed flask and were concentrated to dryness under reduced pressure. The residues were dissolved in $100 \mathrm{~mL}$ TEAAc buffer, $\mathrm{pH} 7$ and they were desalted using a $\mathrm{C}_{18}$ cartridge (Sep-Pak®, Waters) equilibrated with a $100 \mathrm{mM}$ TEAAc buffer solution. The desired compound was eluted with a $12.5 \mathrm{mM}$ TEAAc/ $\mathrm{CH}_{3} \mathrm{CN}(50 / 50)$ solution in a $50 \mathrm{~mL}$ round-bottomed flask and was lyophilized. The residue was dissolved in $1.5 \mathrm{~mL}$ water (divided in 3 portions $0.8 \mathrm{~mL}, 0.4 \mathrm{~mL}$ and $0.3 \mathrm{~mL}$ for flask rinsing), transferred to a $2 \mathrm{~mL}$ Eppendorf-vial and lyophilized. Purified RNAs $\mathbf{8}$ and $\mathbf{9}$ were characterized by MALDI-TOF MS and quantified by UV measurement 


\section{Procedures for conjugation of RNAs in solution}

Preparation of RNA-sugar conjugates 17, 18 and RNA-GSH 19. A 10 $\mathrm{mM}$ solution of of 1 -thio- $\beta$-D-glucose 10 , 1-thio- $\beta$-D-galactose 11 , or glutathione 12 was prepared in HEPES buffer (34 mM NaCl, $1 \mathrm{mM} \mathrm{MgCl}$, $0.05 \mathrm{mM}$ EDTA, $7.5 \mathrm{mM}$ HEPES, pH 8). The buffered solution (10 $\mu \mathrm{L}$ by nmol of RNA) was added to the lyophilized RNA 8 in a $0.5 \mathrm{~mL}$ Eppendorf. The mixture was stirred at $37^{\circ} \mathrm{C}$ for $24 \mathrm{~h}$ using a thermoshaker (Thermal Shake lite $\left.{ }^{\circledR}\right)$. The reaction was stopped by freezing in liquid nitrogen. The RNA conjugates 17, 18 and 19 were purified by IEX-HPLC, desalted and characterized by MALDI-TOF MS using the procedures described above.

Preparation of RNA-4-methylcoumarin conjugate 20. A $10 \mathrm{mM}$ solution of 7-Mercapto-4-methylcoumarin 13 was prepared in 1:1 mixture of HEPES buffer ( $34 \mathrm{mM} \mathrm{NaCl}, 1 \mathrm{mM} \mathrm{MgCl} 2,0.05 \mathrm{mM}$ EDTA, $7.5 \mathrm{mM}$ HEPES $\mathrm{pH}$ 8) and DMF. The buffered solution ( $10 \mu \mathrm{L}$ by nmol of RNA) was added to the freeze-dried RNA 8 in a $0.5 \mathrm{~mL}$ Eppendorf. Then, the mixture was stirred at $37^{\circ} \mathrm{C}$ for $24 \mathrm{~h}$ using a thermoshaker. The reaction was stopped by freezing in liquid nitrogen. The RNA-4-methylcoumarin conjugate $\mathbf{2 0}$ was purified by IEX-HPLC, desalted and characterized by MALDI-TOF spectrometry using the procedures described above.

Preparation of RNA-biotin conjugate 21. A $10 \mathrm{mM}$ solution of (+) - Biotin $N$-2-(pyridin-2-yldisulfanyl)ethyl amide 14 was prepared in 1:1 mixture of HEPES buffer ( $34 \mathrm{mM} \mathrm{NaCl}, 1 \mathrm{mM} \mathrm{MgCl}$, $0.05 \mathrm{mM}$ EDTA, $7.5 \mathrm{mM}$ HEPES $\mathrm{pH}$ 8) and DMF. $100 \mu \mathrm{L}$ of this solution (1000 nmol, 100 equiv.) were diluted with $84 \mu \mathrm{L}$ of HEPES buffer $\mathrm{pH} 8$ and $16 \mu \mathrm{L}$ of a buffered solution of TCEP (50 nmol / $\mu \mathrm{L}, 80$ equiv, ). The mixture was stirred for $2 \mathrm{~h}$ at $37^{\circ} \mathrm{C}$ using a thermoshaker. Then the solution was added to the freeze-dried RNA 8 in a $0.5 \mathrm{~mL}$ Eppendorf and stirred at $37^{\circ} \mathrm{C}$ for $24 \mathrm{~h}$ using a thermoshaker. The reaction was stopped by freezing in liquid nitrogen and the RNA-biotin conjugate $\mathbf{2 1}$ was purified by IEX-HPLC, desalted and characterized by MALDI-TOF MS using the procedures described above.

Preparation of RNA-Dox conjugates 22 and 24. A $10 \mathrm{mM}$ solution of Doxorubicine 2-(pyridin-2-yldisulfanyl)ethylcarbamate 15 was prepared in DMF. $100 \mu \mathrm{L}$ of this solution (1000 nmol, 100 equiv) were diluted with 84 $\mu \mathrm{L}$ of HEPES buffer (34 mM NaCl, $1 \mathrm{mM} \mathrm{MgCl} 2,0.05 \mathrm{mM}$ EDTA, $7.5 \mathrm{mM}$ HEPES, $\mathrm{pH} 8)$ and $16 \mu \mathrm{L}$ of a buffered solution of TCEP $(50 \mathrm{nmol} / \mu \mathrm{L}, 80$ equiv). The mixture was stirred for $2 \mathrm{~h}$ at $37^{\circ} \mathrm{C}$ using a thermoshaker. Then the solution was added to the freeze-dried RNA 8 or 9 in a $0.5 \mathrm{~mL}$ Eppendorf and stirred at $37^{\circ} \mathrm{C}$ for 5 min using a thermoshaker. The reaction was stopped by addition of a large excess of HEPES buffer $\mathrm{pH} 5$. The RNA-Dox conjugates $\mathbf{2 2}$ and $\mathbf{2 4}$ were immediately purified by RP. HPLC, characterized IEX-HPLC and MALDI-TOF MS using the procedures described above

Preparation of RNA-deoxycholic acid conjugate 23. A $10 \mathrm{mM}$ solution of $\quad N$-(2-(pyridin-2-yldisulfaneyl)ethyl)-3a.12 $\alpha$-dihydroxy-5 $\beta$-cholan-24amide 16 was prepared in 2:3 mixture of HEPES buffer $(34 \mathrm{mM} \mathrm{NaCl}, 1$ $\mathrm{mM} \mathrm{MgCl}_{2}, 0.05 \mathrm{mM}$ EDTA, $7.5 \mathrm{mM}$ HEPES, pH 8) and DMF. $100 \mu \mathrm{L}$ of the solution (1000 nmol, 100 equiv) were diluted with $86 \mu \mathrm{L}$ of buffer and $16 \mu \mathrm{L}$ of a buffered solution of TCEP ( $50 \mathrm{nmol} / \mu \mathrm{L}, 80$ equiv). The mixture was stirred for $2 \mathrm{~h}$ at $37^{\circ} \mathrm{C}$ using a thermoshaker. Then, the solution was added to the freeze-dried RNA 8 in a $0.5 \mathrm{~mL}$ Eppendorf and stirred at $37^{\circ} \mathrm{C}$ for $24 \mathrm{~h}$ using a thermoshaker. The reaction was stopped by freezing in liquid nitrogen and the RNA-deoxycholic acid conjugate 23 was purified by RP-HPLC, evaporated and characterized by MALDI-TOF MS using the procedures described above.

Recovery yields for RNA-Dox conjugates $\mathbf{2 2}$ and $\mathbf{2 4}$ were calculated from UV absorption at $481 \mathrm{~nm}$ of the RNA conjugates. Other recovery yields were calculated from UV absorption at $260 \mathrm{~nm}$ of RNA-small molecule conjugates.

Reductive conversion of RNA under glutathione treatment. $1 \mathrm{nmol}$ of RNA-small molecule conjugates (1 nmol) were freeze-dried in $500 \mu \mathrm{L}$ Eppendorf tubes then were dissolved in $100 \mu \mathrm{L}$ of a glutathione-HEPES buffer (34 mM NaCl, 1 mM MgCl , 0.05 mM EDTA, 7.5 mM HEPES, 10 $\mathrm{mM}$ glutathione, $\mathrm{pH} 8$ ) and incubated at $37^{\circ} \mathrm{C}$. For RNA-conjugates 17, 19, 20, 21 and 23, aliquots were collected after $5 \mathrm{~min}, 1.5 \mathrm{~h}, 6 \mathrm{~h}$ and $24 \mathrm{~h}$. For RNA conjugate 18, aliquots were collected after $1.5 \mathrm{~h}, 6 \mathrm{~h}$ and $24 \mathrm{~h}$. For RNA conjugate 22, aliquots were collected after $30 \mathrm{~min}, 4 \mathrm{~h}$ and $24 \mathrm{~h}$. All aliquots were immediately frozen in liquid nitrogen and kept at $-80^{\circ} \mathrm{C}$ until analysis. Samples were diluted with water and analyzed by MALDI-TOF MS.

\section{Acknowledgments}

Florian Gauthier thanks the University of Montpellier for financial support.

Keywords: conjugation $\bullet$ RNA • disulfide bridge $\bullet$ carbamate $\bullet 2$ '$\mathrm{OH}$ modification

[1] X. Ming, B. Laing, Adv. Drug Deliv. Rev. 2015, 87, 81-89.

a) A. Aviñó, S. M. Ocampo, R. Lucas, J. J. Reina, J. C. Morales, J. C. Perales, R. Eritja, Mol. Divers. 2011, 15, 751-757; b) B. UgarteUribe, S. Pérez-Rentero, R. Lucas, A. Aviñó, J. J. Reina, I. Alkorta Uribe, S. Pérez-Rentero, R. Lucas, A. Aviñó, J. J. Reina, I. Alkorta, c) T. S. Zatsepin, T. S. Oretskaya, Chem. Biodivers. 2004, 1, 14011417; d) Y. Ikeda, D. Kubota, Y. Nagasaki, Bioconjugate Chem. 2010, 21, 1685-1690.

[3] a) S. Matsuda, K. Keiser, J. K. Nair, K. Charisse, R. M. Manoharan P. Kretschmer, C. G. Peng, A. V. Kel'in, P. Kandasamy, J. L. S Willoughby, A. Liebow, W. Querbes, K. Yucius, T. Nguyen, S. Milstein, M. A Maier, K. G. Rajeev, M. Manoharan, ACS Chem Biol. 2015, 10, 1181-1187; b) A. D. Springer, S. F. Dowdy, Nucleic Acid Ther. 2018, 28, 109-118

[4] L. He, Q. Xu, Y. Liu, H. Wei, Y. Tang, W. Lin, ACS Appl. Mater Interfaces 2015, 7, 12809-12813.

a) G. Russell-Jones, K. McTavish, J. McEwan, J. Rice, D. Nowotnik J. Inorg. Biochem. 2004, 98, 1625-1633; b) W. X. Ren, J. Han, S Uhm, Y. J. Jang, C. Kang, J.-H. Kim, J. S. Kim, Chem. Commun 2015, 51, 10403-10418.

[6] a) J. R. Dunetz, J. Magano, G. A. Weisenburger, Org Process Res. Dev. 2016, 20, 140-177; b) A. V. Kachalova, D. A. Stetsenko, E. A Romanova, V. N. Tashlitsky, M. J. Gait, T. S. Oretskaya, Helv. Chim. Acta 2002, 85, 2409-2416.

[7] a) Y. Singh, E. Defrancq, P. Dumy, J. Org. Chem. 2004, 69, 8544 8546; b) D. Forget, D. Boturyn, E. Defrancq, J. Lhomme, P. Dumy, Chem. Eur. J. 2001, 7, 3976-3984.

[8] a) T. Yamada, C. G. Peng, S. Matsuda, H. Addepalli, K. N. Jayaprakash, M. R. Alam, K. Mills, M. A. Maier, K. Charisse, M. Sekine, M. Manoharan, K. G. Rajeev, J. Org Chem. 2011, 76, 11981211; b) W. Wang, K. Chen, D. Qu, W. Chi, W. Xiong, Y. Huang, J. Wen, S. Feng, B. Zhang, Tetrahedron Lett. 2012, 53, 6747-6750; c) M. Gerowska, L. Hall, J. Richardson, M. Shelbourne, T. Brown, Tetrahedron 2012, 68, 857-864.

[9] M. H. Lee, Z. Yang, C. W. Lim, Y. H. Lee, S. Dongbang, C. Kang, J. S. Kim, Chem. Rev. 2013, 113, 5071-5109.

[10] a) H. Lönnberg, Bioconjugate Chem. 2009, 20, 1065-1094; b) F Maurel, F. Debart, F. Cavelier, A. R. Thierry, B. Lebleu, J.-J. Vasseur, E. Vivès, Bioorg Med Chem Lett 2005, 15, 5084-5087; C) W. H. A. Kuijpers, C. A. A. van Boeckel, Tetrahedron 1993, 49 10931-10944; d) Y.-H. Rogers, P. Jiang-Baucom, Z.-J. Huang, V Bogdanov, S. Anderson, M. T. Boyce-Jacino, Anal Biochem 1999, 266, 23-30; e) D. R. Corey, Methods Mol. Biol. 2004, 283, 197-206.

[11] a) C. He, G. L. Verdine, Chem Biol 2002, 9, 1297-1303; b) H. Huang S. C. Harrison, G. L. Verdine, Chem Biol 2000, 7, 355-364; c) S. R. Paalman, D. M. Noll, N. D. Clarke, Nucleic Acids Res. 1997, 25, 1795-1801. 
[12] S. Pérez-Rentero, S. Grijalvo, R. Ferreira, R. Eritja, Molecules 2012 17, 10026.

[13] M. Dirin, E. Urban, C. R. Noe, J. Winkler, Eur. J. Med. Chem. 2016 121, 132-142.

[14] V. Metelev, A. Romanenkov, E. Kubareva, E. Zubin, N. Polouchine, T. Zatsepin, N. Molochkov, T. Oretskaya, IUBMB life 2006, 58, 654658.

[15]

a) A. Biscans, S. Rouanet, J.-J. Vasseur, C. Dupouy, F. Debart, Org. Biomol. Chem 2016, 14, 7010-7017; b) F. Gauthier, S. Claveau, J. R. Bertrand, J.-J. Vasseur, C. Dupouy, F. Debart, Bioorg. Med. Chem. 2018, 26, 4635-4643.

[16]

F. Gauthier, F. Beltran, A. Biscans, F. Debart, C. Dupouy, J.-J. Vasseur, Org. Biomol. Chem 2018, 16, 3181-3188.

[17] A. K. Ghosh, M. Brindisi, J. Med. Chem. 2015, 58, 2895-2940.

[18] a) A. Misra, S. Mishra, K. Misra, Bioconjugate Chem. 2004, 15, 638 646; b) K. Seio, R. Tawarada, T. Sasami, M. Serizawa, M. Ise, A Ohkubo, M. Sekine, Bioorg. Med. Chem. 2009, 17, 7275-7280; c) K. Seio, M. Tokugawa, T. Kanamori, H. Tsunoda, A. Ohkubo, A Sekine, Bioorg. Med. Chem. Lett. 2012, 22, 2470-2473; d) M.
Prhavc, E. A. Lesnik, V. Mohan, M. Manoharan, Tetrahedron Lett 2001, 42, 8777-8780; e) N. N. Dioubankova, A. D. Malakhov, D. A Stetsenko, M. J. Gait, P. E. Volynsky, R. G. Efremov, V. A. Korshun, ChemBioChem 2003, 4, 841-847.

[19] T. Lavergne, J.-R. Bertrand, J.-J. Vasseur, F. Debart, Chem. Eur. J. 2008, 14, 9135-9138.

[20] a) G. Sengle, A. Jenne, P. S. Arora, B. Seelig, J. S. Nowick, A Jäschke, M. Famulok, Bioorg. Med. Chem. 2000, 8, 1317-1329; b) V. Noponen, H. Belt, M. Lahtinen, A. Valkonen, H. Salo, J. Ulrichová, A. Galandáková, E. Sievänen, Steroids 2012, 77, 193-203.

[21] A. Latorre, P. Couleaud, A. Aires, A. L. Cortajarena, Á. Somoza, Eur. J. Med. Chem. 2014, 82, 355-362.

[22] a) H. Meng, M. Liong, T. Xia, Z. Li, Z. Ji, J. I. Zink, A. E. Nel, ACS Nano 2010, 4, 4539-4550; b) A. M. Chen, M. Zhang, D. Wei, D. Stueber, O. Taratula, T. Minko, H. He, Small 2009, 5, 2673-2677. D. Kaushik, G. Bansal, J. Pharm. Anal. 2015, 5, 285-295. 


\section{Entry for the Table of Contents}

\section{FULL PAPER}

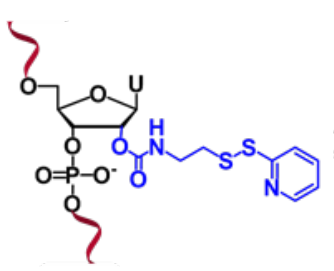

$\underset{\begin{array}{c}\text { solution phase } \\ \text { conjugation }\end{array}}{\stackrel{\text { R-SH }}{\longrightarrow}}$
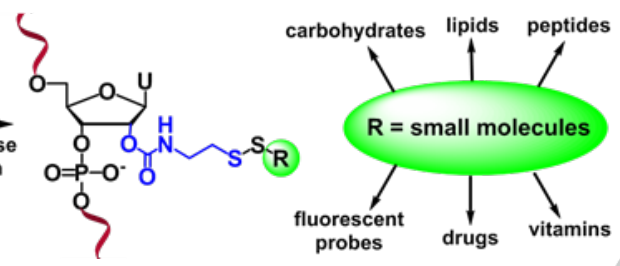

In this paper, we developed a post-synthesis conjugation of small molecules to RNA using a reduction sensitive disulfide linker connected to $2^{\prime} \mathrm{OH}$ via a carbamate function.

\section{RNA conjugation}

F. Gauthier, A. Malher, J.J Vasseur, C. Dupouy*, F. Debart*

Page No. - Page No.

Conjugation of small molecules to RNA using a reducible disulfide linker attached at 2'-OH position via a carbamate function. 